\title{
Health and Culinary Art in Antiquity AND EARLY BYZANTIUM IN THE LIGHT OF DE RE COQUiNaria
}

It is well known even to the modern general public that Hippocratic physicians, putting a particular emphasis on nutrition, considered each sort of food an actual medicine, i.e. a substance by virtue of which human health is maintained or restored $^{1}$. It is also of the utmost importance for the line of reasoning adopted in the present study ${ }^{2}$ that this Hippocratic doctrine $e^{3}$ became commonly accepted in the medical milieu of his fellow doctors and therefore resulted in a considerable and permanent interest in food on the part of his Greek and later Roman follow$\mathrm{ers}^{4}$. We should additionally underscore the fact that there was yet another result of the acceptance of Hippocrates' teachings, the consequence of which has not been satisfactorily verbalized so far in modern research. The stress put by Hippocrates on the issue of food shifted the interest of medical doctors close to the area of activity of cooks ${ }^{5}$, thus, on the one hand, making medicine a sort of a theoretical

1 Hippocrate, De alimento, 19, [in:] Oeuvres completes d'Hippocrate, vol. IX, ed. E. Littre, Paris 1861.

2 An analogous approach cf. M. Кокоszко, Aromaty kuchni antyku i Bizancjum w teorii medycznej i praktyce kulinarnej, PH 102.4, 2011, p. 535-565, especially 535-544.

3 The system of Hippocratic dietetics can be retrieved from the whole heritage of the famous medical doctor. However, especially informative are De natura hominis (Hippocrate, De natura hominis, [in:] Oeuvres complètes d'Hippocrate, vol. VI, ed. E. Littre, Paris 1849) and De diaeta (Anonymus, De diaeta, [in:] Physici et medici Graeci minores, vol. II, ed. J.L. Ideler, Amsterdam 1963). On the main concepts of the Hippocratic school (including food) - V. Nutton, Galen and the traveler's fare, [in:] Food in Antiquity, ed. J. Wilkins, D. HARvey, M. Dobson, Exeter 1995, p. 359-370; IDEM, Ancient medicine, London-New York 2007, p. 72-86, esp. 77-85. An in-depth study on the role of food in Corpus Hippocraticum - S. BYL, Lalimentation dans le Corpus Hippocratique, [in:] Voeding en geneeskunde / Alimentation et médecine. Acten van het colloquium / Actes du colloque Brussel-Bruxelles 12. 10. 1990, ed. R. Jansen-Sieben, F. Daelmans, Brussel/Bruxelles 1993, p. 29-39.

4 A comprehensive and informative outline of the development of ancient dietetics up to the time of Galen cf. K. Bergoldt, Wellbeing. A cultural history of healthy living, transl. J. Dewhurst, Cambridge-Malden, Massachusetts 2008, p. 30-37, 41-46, 62-72.

5 Actually, one can even come to the conclusion that it was Greek medicine that evolved out of traditional culinary practice. It was Herodicus of Selymbria, believed by later authors to be one of 
basis of the culinary practice of Antiquity, while, on the other hand, encouraging medics to analyze culinary tradition as a resource of potential medicaments.

After centuries, but still in the period of Antiquity, an eminent medical doctor born in Pergamum, namely Galen, educated in the teachings of the Hippocratic school and fully convinced of the fact that those were scientifically justified, went on to further develop Hippocrates' research. Being a hardworking practitioner and a prolific writer, he left a cornucopia of works (the majority of which are still extant) in which he taught what and under what circumstances should be consumed by humans so that they could lead a healthy and happy life. As a consequence, he included in his treatises an exceptionally high number of details referring to selecting, correctly processing and effectively making use of different foodstuffs, thus leaving for modern researchers much information not only on medical practices typical of his times but also on the tradition of culinary art up to his lifetime ${ }^{6}$.

Galen's doctrines in turn left an equally lasting imprint on teachings of his contemporaries as well as on those of later generations of medical doctors, for whom Galen became the paragon of all virtues. Having accepted his doctrines, medical authorities such as Oribasius, refrained from modifying but rather tended to repeat his theories through summarizing $\mathrm{Galen}^{7}$. As a result, their works include teachings typical of Galenism, thereby containing a vast body of data on ancient dietetics as well as including various and important references to culinary practices. Consequently, they have also become an indispensible source for any modern student of ancient gastronomy.

It should also be mentioned that the knowledge of dietetic properties of food was disseminated in Antiquity and early Byzantium not only through medical treatises stricto sensu, and in consequence, as we surmise, was relatively broadly known. Such a conclusion is supported, among others, by the extant literary output. An example of literature that to a considerable extent took into consideration

Hippocrates' mentors, who constitutes the link between one and the other - V. Nutron, Ancient medicine..., p. 96-97.

6 A reference to a couple of examples of Galen's familiarity with culinary practices will suffice for the purpose of the present study. In his treatise on basic foodstuffs (Galeni de alimentorum facultatibus libri, 461, 7-11, [in:] Claudii Galeni opera omnia, vol. VI, ed. D.C.G. KüHN, Lipsiae 1823 (cetera: Galen, De alimentorum facultatibus) he includes a recipe for the double cooking of cabbage, which surely reflects a culinary technique still in use at his time (though equally recommended at a later date-Oribasii collectionum medicarum reliquiae, III, 30, 6, 1 - 7, 1, ed. I. RAEDER, vol. I-IV, Lipsiae-Berolini 1928-1933 [cetera: Oribasius, Collectiones medicae]; Aetii Amideni libri medicinales I-VIII, I, 221, 7-13, ed. A. OliVIERI, Lipsiae-Berolini 1935-1950 (cetera: Aetius of AmIdA, Iatricorum libri). On the method of cooking cabbage also cf. M. Kокоszko, K. JaGusiaK, Warzywa w kuchni i dietetyce późnego antyku oraz wczesnego Bizancjum (IV-VII w.). Perspektywa konstantynopolitańska, PZH 12.1, 2011, p. 42-43. We also learn from Galen's writings (GALEN, De alimentorum facultatibus, 716, 9-14) that red mullets, i.e. triglai, were eaten with a sauce prepared on the basis of garelaion (i.e. fish sauce, garum, mixed with olive oil). On the red mullet cf. M. Koкоszко, Ryby i ich znaczenie w życiu codziennym ludzi późnego antyku i wczesnego Bizancjum (III-VII w.), Łódź 2005, p. 358-364.

7 V. Nutton, Ancient medicine..., p. 292-309, especially 309. 
the achievements of both ancient culinary art and dietetics is the work of a philological and antiquarian nature entitled Deipnosophists, compiled by Athenaeus of Naucratis ${ }^{8}$. In this work, a certain Galen is presented as one of the feasting sophists ${ }^{9}$, while comments concerning the properties of foods are present practically throughout the whole text, including sometimes substantial fragments of medical works (by Hippocrates, Diocles of Carystus ${ }^{10}$, Mnesitheus ${ }^{11}$, Diphilus of Siphnus $^{12}$ and by numerous others), which constitute an integral part of the deliberations of the sophists feasting and conversing at the table. Discussion of food along with its medical (including dietetic) properties is also part of Roman agronomical heritage, which is clearly visible, for example, in De agri cultura by Cato the Elder $\left(3^{\text {rd }}-2^{\text {nd }} \text { cent. B.C. }\right)^{13}$ or in the extant fragments of De pomis seu medicina ex pomis by Gargilius Martialis ( $3^{\text {rd }}$ cent. A.D. $)^{14}$. No wonder that a similar approach is also discernible in Byzantine agronomy, which also profited from Roman expertise. A good example is constituted by the so-called Geoponica (10 th $c e n t$. A.D.). Examples of dietetics-related doctrines present in the other work come thick

8 That is why the work lends itself to being profited from in elucidating various food-related issues, for instance data considering fish. Cf. M. Кокоszко, Ryby..., passim. On Athenaeus' interest in medicine (including its dietetic branch) and its heritage cf. J.-N. CoRvisier, Athenaeus, medicine and demography, [in:] Athenaeus and his world. Reading Greek culture in the Roman Empire, ed. D. BRAund, J. Wilkins, foreword by G. Bowersock, Exeter 2000, p. 492-502; R. Flemming, The physicians at the feast. The place of the medical knowledge at Athenaeus' dinner table, [in:] Athenaeus and..., p. 476-482.

9 V. Nutton, Galen and..., p. 368-369.

${ }_{10}$ A renowned medical doctor who was active at the end of the $4^{\text {th }}$ cent. B.C. Cf. M. Wellmann, Diokles (53), [in:] RE, vol. V, Stuttgart 1905, col. 802-812; K.-H. Leven, Diokles v. Karystos, [in:] Antike Medizin. Ein Lexikon, ed. K.-H. Leven, München 2005, p. 225-227; V. Nutton, Ancient medicine..., p. $120-123$.

${ }^{11}$ Born in Athens or in Cyzicus. He was active most probably in the $4^{\text {th }}$ cent. B.C, when he authored a work which is usually termed On foodstuffs, which was devoted to both animal as well as plant food. He was known to Galen (and actually is considered to have been one of his main sources as far as dietetics was concerned [cf. V. NutTon, Galen and..., p. 361-362]), and quoted by Oribasius, who preserved, for instance, his recipe for cooked cabbage (Oribasius, Collectiones medicae, IV, 4, $1-5$, 2). Equally profited from by Athenaeus of Naucratis, for example in book VIII of his Deipnosophists as an authority on fish. Cf. A. DALbY, Food in the Ancient World from A to Z, London-New York 2003, p. 220-221; R. De Lucia, Mnesitheos, [in:], Antike Medizin..., p. 623-624; K. Deichgräвer, Mnesitheos

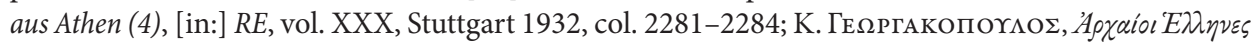

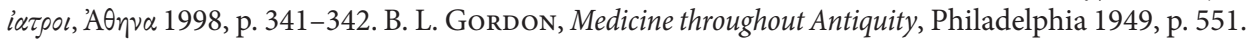
12 Diphilus of Siphnus lived in the second part of the $4^{\text {th }}$ and in the first of the $3^{\text {rd }}$ cent. B.C. He was a court physician of king Lysimachus. He authored a treatise in which he characterized kinds of food appropriate for the healthy and the ill and which is mentioned by Athenaeus of Naucratis at multiple occasions - J. Scarborough, Diphilus of Siphnus and Hellenistic medical dietetics, JHM 25, 1970, p. 194-201; M. Stamatu, Diphilos v. Siphnos, [in:] Antike Medizin..., p. 230.

${ }_{13}$ For example, cf. Cato's list of medicinal wines - Marci Porcir Catonis, De agri cultura, 122-127, ed. A. Mazzarino, Lipsiae 1982 (cetera: Cato, De agri cultura) and his descriptions of cabbage (156-157).

${ }^{14}$ Cf. fragments printed in I. МıкоєАјсzук, Rzymska literatura agronomiczna, Toruń 2004, p. 293-301. 
and fast, but for our purposes it will suffice to quote a fragment of the Geoponica wherein the author discusses radish, raphanos, providing more or less exhaustive information on the dietetic properties of this plant ${ }^{15}$. We should equally remember Anthimus' De observatione ciborum ${ }^{16}$. It is a sui generis melange of medical and gastronomic knowledge, which in a brief manner merges the output of thought in the said areas, bringing the knowledge of generations down to practical suggestions concerning healthy nutrition, and addressed to Theuderic, the ruler of the Francs. It was written in the $6^{\text {th }}$ century in Latin by the Greek physician Anthimus. Finally, the popularity of dietetic doctrines contributed to the compilation of sui generis dietetic calendars ${ }^{17}$ whose extant example is the work of Hierophilus the Sophist $\left(7^{\text {th }} \text { cent. A.D. }\right)^{18}$. The text ${ }^{19}$ included simplified medical doctrines in the form of advice which foodstuffs should be consumed in which month of the year.

Obviously, we should not assume that the art of culinary masters always followed the guidelines of medical theoreticians. On the contrary, breaches of dietetic rules were quite frequent. Galen, for instance, writes a lot about improper ways of preparing ptisane, the legendary barley soup of medicinal properties. Those blameworthy practices included pounding pearl barley in the mortar (instead of making use of entire grains after careful removal of their husks), cooking it on a big fire for a short time (instead of simmering it till the pearl barley becomes entirely tender)

15 Cf. Geoponica sive Cassiani Bassi Scholastici de re rustica ecloguae, XII, 22, rec. H. ВЕСКн, Lipsiae 1895 (cetera: Geoponica).

16 Anthimus, On the observance of foods. De observatione ciborum, trans. M. Grant, Totnes-Blackawton 2007 (cetera: Anthimus, De observatione ciborum). Cf. M. Koкоszко, [rec.:] Anthimus, On the observance of foods. De observatione ciborum, translated and edited by Mark Grant, $2^{\text {nd }}$ edition, Blackawton, Totnes, Devon 2007, ss. 142, PNH 8.2, 2009, p. 245-255. A good instance of dietetic approach of the author are Anthimus' reflections on beef - ANTHImus, De observatione ciborum, III.

17 The calendars of the Byzantine era had their predecessors in antiquity but also were heavily dependent on the doctrines known to the early Byzantines. The problem has been quite recently researched into by Francesca Pucci Donati [(Dieta, salute, calendari. Dal regime stagionale antico ai regimina mensium medievali: origine di un genere nella letterature medica occidentale, Spoleto 2007, passim, esp. p. 65-69 (Galen and dietary calendars), 74-76 (Anthimus and dietary calendars), 78 (Oribasius and dietary calendars), 89-94 (Paul of Aegina and dietary calendars)]. One should also remember that there are quite strong ties between dietetics and astronomy (the latter determining regimina mensium), since the movement of stars and planets was thought to have an impact on proprerties of food and human health - A. PÉRez Jiménez, Peri deípnou. Referencias astrólgicas antiguas a la dieta y la gastronomía, [in:] Dieta Mediterránea. Comidas y hábitos alimenticios en las culturas Mediterráneas, ed. A. Pérez Jiménez, G. Cruz Andreotti, Madrid 2000, p. 125-131.

18 A. Dalby, Flavours of Byzantium, Blackawton-Totnes 2003, p. 52-55; IDEM, Tastes of Byzantium. The cuisine of a legendary empire, London-New York 2010, p. 52-55; H. Hunger, Die hochsprachliche profane Literatur der Byzantiner, vol. II, München 1978, p. 309; J. Koder, Gemüse in Byzanz. Die Konstantinopels mit Frischgemüse im Lichte der Geoponika, Wien 1993, p. 38.

${ }^{19}$ Hierophilou philosophou pos opheilei diaitasthai anthropos eph' hekasto meni, [in:] Anecdota Atheniensia et alia, vol. II, ed. A. Delatte, Liége-Paris 1939, p. 455-466 (cetera: Hierophilus). An English translation of the work - A. DALBY, Flavours..., p. 161-169; IDEM, Tastes..., p. 161-169. 
and adding to it reduced wine must, cumin and honey ${ }^{20}$. Oribasius, in turn, informs that some cooks enriched fake, the famous lentil soup, with reduced must, i.e. siraion. This practice must have been considered as inappropriate from a medical point of view, for the famous doctor did not recommend this additive. Instead, he suggested preparing the dish adding savoury, pennyroyal (in order to enhance the digestibility of the whole dish) and pork akrokolia (optimally cured ones) ${ }^{21}$.

It should be noted that references to the therapeutic role of food is also visible in the sole ancient cookery book that has survived to our times, known under the Latin title De re coquinaria, the authorship of which is attributed by tradition to a certain Apicius, a Roman gourmet who lived at the beginning of the $1^{\text {st }}$ century A.D. ${ }^{22}$ However, this customary attribution is usually questioned by modern science on a number of grounds. According to the recently published results of research conducted by Christopher Grocock and Sally Grainger ${ }^{23}$, the collection has many authors, but their identification is impossible. These were numerous nameless masters of gastronomy ${ }^{24}$, who in all probability had no education ${ }^{25}$. They belonged to the lower social classes, for the entire ancient culinary art was the domain of highly proficient slaves and/or persons who were not members of the contemporary elites ${ }^{26}$. Grocock and Grainger maintain that at least some of the recipes were (initially at least) handed down verbally. It is also possible that certain recipes were not written down by their authors, but instead dictated (to those who possessed the skill of writing $)^{27}$. Furthermore, the researchers consider it highly probable that a certain fragment of the collection constituted the output of one the ancient culinary schools. Their members wrote down their own recipes and exchanged them between themselves. It was in such circles that the recipes (initially circulating individually) were compiled into a whole book ${ }^{28}$.

In the present study we would like to turn the attention of the readers only to the most obvious aspects of the connection between De re coquinaria and ancient therapeutic practices, namely to the recipes (expressis verbis) hinting at some medicinal

${ }^{20}$ Galeni qui fertur de ptisana libellus, 821, 7-10, [in:] Corpus medicorum Graecorum, vol. V, 4, 2, ed. O. Hartlich, Leipzig 1923 (cetera: GAlEn, De ptisana).

${ }^{21}$ Oribasius, Collectiones medicae, IV, 1, 22, $1-26,1$. The term akrokolia refers to trotters, i.e. feet, mainly of a pig. Cf. A. Dalby, Food..., p. 269.

22 Ch. Grocock, S. Grainger, Introduction, [in:] Apicius. A critical edition with an introduction and an English translation of the Latin recipe text Apicius, ed. EIDEM, Blackawton-Totnes 2006 (cetera: Apicius), p. 54-58.

${ }_{23}$ The whole of their research results is worth recommending - Ibidem, p. 13-123.

${ }^{24}$ The latest reflections on the professional and social position of Roman cooks cf. R.I. CURTIs, Professional cooking, kitchens, and work service, [in:] A cultural history of food in Antiquity, ed. P. ERDKAMP, London-New York 2012, p. 113-132.

${ }_{25}$ Ch. Grocock, S. Grainger, Introduction..., p. 13.

26 Ibidem, p. 13, 18.

${ }^{27}$ Ibidem, p. 91.

${ }^{28}$ Ibidem, p. 69-71. 
properties of dishes and to the dishes themselves, which have numerous analogies with a clear indication of a therapeutic action in ancient and early Byzantine medical literature. There are a number of them. Namely, in the first book of De re coquinaria, entitled The Provident Cook, i.e. Epimeles in the Latinized Greek of the collection ${ }^{29}$, we find recipes for a medium that facilitates digestion (oxyporum) ${ }^{30}$; for two varieties of sauces (or dressings) ${ }^{31}$ based on fish sauce (i.e. garum), namely a type termed oxygarum digestibile $e^{32}$ and a sort called oenogarum (in tubera) ${ }^{33}$; for herbal salts (sales conditi $^{34}$; and for a few beverages, such as spiced wine (conditum paradoxum) ${ }^{35}$, a sort of honeyed wine (or mead) spiced with pepper - recommended for travellers (conditum melizomum viatorum $)^{36}$, Roman absinthe (absintium Romanum $)^{37}$ and rosehip wine (rosatum) ${ }^{38}$. The third book, entitled Cepuros (Garden) or De oleribus (On vegetable dishes), contains in turn recipes for a dish known as pulmentarium ${ }^{39}$, that is - as explained by Andrew Dalby, a renowned expert on ancient and Byzantine dietetics ${ }^{40}$, and the author of the newest English translation of Geoponica ${ }^{41}$ - a soup made on a vegetable or fruit purée base ${ }^{42}$. Next, in the fourth book, entitled Pandecter, we encounter yet another dish which, depending on the variant, is known as tisana vel sucus ${ }^{43}$ or tisana barrica $^{44}$. Furthermore, De re coquinaria contains a prophylactic recommendation to eat nettles in order to avoid health problems ${ }^{45}$.

${ }^{29}$ The Latinized but originally Greek titles of the books are an interesting hint at the evolution of Roman culinary art, which was a creative continuation of much earlier Greek patterns.

30 Apicjusz, O sztuce kulinarnej ksiąg dziesięć, I, 32, trans. I. Мıкоєајсzyк, S. Wyszomirsкi, Toruń 1998 (cetera: Apicjusz); Apicius, I, 32. The recipe was later repeated in book III, cf. Apicjusz, III, 18, 2-3; Apicius, III, 18, 2.

31 J. Solomon, The Apician sauce. Ius Apicianum, [in:] Food in Antiquity..., p. 115-131.

${ }^{32}$ Apicjusz, I, 34, 1-2; Apicius, I, 34.

33 Apicjusz, I, 31; Apicius, I, 31.

${ }^{34}$ Apicjusz, I, 27; Apicius, I, 27.

${ }_{35}$ Apicjusz, I, 1, 1; Apicius, I, 1.

${ }^{36}$ Apicjusz, I, 2; Apicius, I, 2.

37 Apicjusz, I, 3; Apicius, I, 3.

38 Apicjusz, I, 4, 1; Apicius, I, 4.

39 Apicjusz, III, 2, 1-5; Apicius, III, 2, 1-4.

40 The author is one of the most active researchers and prolific writers in the field of ancient and Byzantine history of food, and has considerably contributed to noticeable progress of our knowledge on over last decades. His bibliography includes (among others) A. DALbY, Siren feasts. A history of food and gastronomy in Greece, London-New York 1996; IDEM, Dangerous tastes. The story of spices, London 2000; IDEM, Empire of pleasures. Luxury and indulgence in the Roman world, London-New York 2000; IDEM, Food... etc. We also would like to remind the reader of the present article that he has already been mentioned as the author of two publications on Byzantine cuisine.

${ }^{41}$ Geoponika: Farm work, a modern translation of the Roman and Byzantine farming handbook, trans.

A. Dalby, Totnes-Blackawton 2011.

42 A. Dalby, Food..., p. 307.

43 Apicjusz, IV, 4, 1; Apicius, IV, 4, 1.

${ }^{44}$ Apicjusz, IV, 4, 2; Apicius, IV, 4, 2.

${ }^{45}$ Apicjusz, III, 17; Apicius, III, 17. 
We will commence our analysis with the oxyporum ${ }^{46}$. The recipe for this additive to dishes is relatively precise, for it even gives the exact gram weight of ingredients. In accordance with the recipe, you should pour wine vinegar over cumin (Ethiopian, Libyan or Syrian ${ }^{47}$ ), then dry the ingredients and grind them into powder in a mortar. Next, the powder is to be added to a mass comprising two ounces ${ }^{48}$ of cumin, an ounce of ginger, the same quantity of green rue and pepper, six scripuli ${ }^{49}$ of soda, twelve scripuli of juicy dates and nine ounces of honey. Finally, the mixture thus obtained should be dissolved in a quantity of one half of a cochlear $e^{50}$ of a mixture of vinegar and fish sauce (garum).

The recipe from the first book of De re coquinaria does not contain any mention of the medicinal applications of this mixture. These have been given only in the commentary of an anonymous author in book three, who states that oxyporum is served as an additive to lettuce (together with wine vinegar and a drop of garum/liquamen) and as such it facilitates digestion, lessens the carminative effect of some (unspecified) foods and, specifically in the case of lettuce, does not allow the vegetable to do harm (i.e. disturb organic processes) ${ }^{51}$.

We do not know what digestive or other anomalies the author of the recipe from De re coquinaria had in mind, especially since lettuce was a relatively popular vegetable (both in antiquity, and in Byzantium), with numerous varieties, both wild and cultivated, being known. The history of lettuce in the Mediterranean world is very long. It was consumed as early as the $3^{\text {rd }}$ millennium B.C. in Egypt. In Greece and Rome, the vegetable was also popular and universally consumed ${ }^{52}$. This positive image of the lettuce as a healthy, liked and commonly consumed vegetable is supported by the attention given to it by writers and experts on ancient cuisine, such as - for example - Athenaeus of Naucratis ${ }^{53}$. It cannot therefore surprise us that discussions and deliberations on various

${ }^{46}$ The majority of termini technici used in the present text has been recently explained and characterized by Масіеј Кокоszко (Smaki Konstantynopola, [in:] Konstantynopol - Nowy Rzym. Miasto i ludzie w okresie wczesnobizantyńskim, ed. M.J. LeszKa, T. WolińsKa, Warszawa 2011, p. 471-575). A very informative guide to the issue - A. DALBY, Food..., passim.

47 These are varieties of Cyminum cyminum L. cultivated respectively in Ethiopia, Libya and Syria - S. Wyszomirsкi, I. MiкоєајCzyк, Identyfikacja roślin i przypraw ochodzenia roślinnego u Apicjusza, [in:] Apicjusz, p. 299.

48 One ounce $=27.2$ grams.

49 One scripulus $=1.1$ grams.

50 One cochleare $=0.011$ litre.

${ }^{51}$ Apicjusz, III, 18, 3; Apicius, III, 18, 2.

52 A. Dalby, Food..., p. 196; A. Davidson, Lettuce, [in:] Oxford Companion to food, ed. A. Davidson, Oxford 1999, p. 451-452; J. Koder, Gemüse..., p. 54, 62, 81, 85, 90, 95; M. Koкоszko, Smaki Konstantynopola..., p. 526-527; М. Kокоszко, K. JaGUsiaK, Warzywa..., p. 45-46.

${ }^{53}$ Athenaei Naucratitae deipnosophistarum libri XV, II, 68f - 70a (79, 1 - 81, 22, KAIBEL), rec. G KAIBEL, vol. I-III, Lipsiae-Berolini 1887-1890 (cetera: Athenaeus of Naucratis, Deipnosophistae). 
features of lettuce were also the focus of dieticians such as Galen ${ }^{54}$, Oribasius ${ }^{55}$ or Paul of Aegina ${ }^{56}$. Oribasius recommended it highly. He wrote that although vegetables are usually harmful and lead to an imbalance of juices in the body, lettuce is a notable exception to this rule. Indeed, it stimulates the generation of good blood, which is able to correctly nourish the body. Furthermore, it contains a lot of humidity and serves to cool the body. At this point, however, we must introduce one more proviso. Green vegetables were not one of the favourite foods of antiquity. As a matter of fact, they were associated with the poor, while - for example - Aetius of Amida, a famous physician who lived in the $6^{\text {th }}$ century, wrote that they should be consumed only in small quantities, for they cause gases ${ }^{57}$.

Returning to the oxyporum, we should state that recipes for this specific preparation are extant not only in De re coquinaria, but it is also present in Columella's agronomical treatise ${ }^{58}$. The ingredients that are repeated in both works include pepper (Columella mentions white or black pepper) and honey. Both were to be dissolved in a solution of garum and vinegar. We should therefore suppose that these four ingredients were the basic elements of oxyporum.

As regards the medical classification of the medium, medical treatises indicate that it was classified amongst agents facilitating digestions, i.e. peptika ${ }^{59}$. Greek medical sources lead us to the conclusion that the name used by the author of the recipe set forward in De re coquinaria is a Latinized form of the Greek

\footnotetext{
${ }^{54}$ For example - GALEN, De alimentorum facultatibus, 624, 12 - 628, 7.

55 For example - Oribasius, Collectiones medicae, II, 1, 1, 1-4.

${ }_{56}$ Paulus Aegineta, I, 74, 1, 1-3, ed. I. L. Heiberg, vol. I-II, Lipsiae-Berolini 1921-1924 (cetera: PAUL of Aegina, Epitome).

57 Aetius of AmidA, Iatricorum libri, IX, 35, 173, [in:] Aetiou Amidenou logos enatos, "Athena" 23, 1911, p. 273-390. Cf. J. Koder, Stew and salted meat - opulent normality in the diet of every day?, [in:]: Eat, drink and be merry (Luke 12:19). Food and wine in Byzantium. In honour of Professor A.A.M. Bryer, ed. L. BRUBAKER, K. LinARdou, Aldershot 2007, p. 67, 71. However, in dietary calendars lettuce itself was recommended as good and therefore healthy food in the months of April and June - Hierophilus, p. 460 (Meni Aprilio). Cf. J. Koder, Stew..., p. 67-68; A. DAlby, Flavours..., p. 164; IDEM, Tastes..., p. 164.

${ }^{58}$ L. Iuni Moderati Columellae res rustica, XII, 4-5, [in:] L. Iuni Moderati Columellae res rustica: incerti auctoris liber de arboribus, ed. R.H. RoDGERs, Oxford 2010. The ingredients that differ between the two recipes are celery seeds, asafetida, cheese, skinless dried grapes and dry mint.

59 The above-mentioned application of the specified concoction is preserved in medical works of Byzantium. For example - Oribasii eclogae medicamentorum, XLV, 7, 1 - 8, 1, [in:] Oribasii collectionum medicarum reliquiae, vol. IV, ed. I. RAEDER, libros XLIX-L, libros incertos, eclogas medicamentorum, indicem continens, Lipsiae-Berolini 1933 (cetera: Oribasius, Eclogae medicamentorum); Aetius of Amida, Iatricorum libri, IX, 24, 1-117; PaUl of Aggina, Epitome, III, 28, 12, 1-7. On similar compound medicines cf. M. Kокоszко, Medycyna bizantyńska o antidotum z trzech rodzajów pieprzu. Komentarz na temat jednego ze środków farmaceutycznych zastosowanych w leczeniu Aleksego I Komnena, [in:] Byzantina Europaea. Księga jubileuszowa ofiarowana profesorowi Waldemarowi Ceranowi, ed. M. KoKoszko, M.J. LeszKa, Łódź 2007, p. 253-264, esp. 256 (on oxyporon).
} 
terms oxyporon $n^{60}$, oxyporos ${ }^{61}$ or oxyporion ${ }^{62}$, which have survived in the works of Galen, Oribasius and Aetius of Amida. There were numerous variants of the recipe, while the modification of ingredients was intended not only to change its taste, but first and foremost to remove undesirable juices from the body of the consumer. Lists of such additives that changed the action of oxyporum have survived to the present day, for example in the extant recipes of Aetius of Amida ${ }^{63}$. To sum up, oxyporum was a medium that served to support regulation of the balance of the humours, including problems with the digestive tract. It was used as sui generis additive to dishes ${ }^{64}$ or taken after meals in order to facilitate the metabolism of heavy foods ${ }^{65}$.

The next item on our list is oxygarum digestibile, which in essence was a sauce made from fermented fish garum/liquamen, mixed in equal proportions with wine vinegar $^{66}$. It is highly probable, therefore, that - similarly to oxyporum - it was poured over the ready dish ${ }^{67}$, or that pieces of the dish (for example pieces of meat) were dipped in $i^{68}$. In the analysed work we may find two variants of oxygarum digestibile. In accordance with the first recipe, it was necessary to grind half an ounce

${ }^{60}$ Some examples - Galeni de compositione medicamentorum secundum locos libri, 637, 14, [in:] Claudii Galeni opera omnia, ed. D.C.G. KüHN, vol. XII-XIII, Lipsiae 1826-1827; OrIBAsIUs, Eclogae medicamentorum, XLV, 5, 1; Paul of Aegina, Epitome, III, 9, 3, 15.

${ }^{61}$ For example - Aetius of Amida, Iatricorum libri, IX, 23, 59.

62 For example - Aetius of Amida, Iatricorum libri, IX, 24, 70-99.

${ }^{63}$ Cf. also two oxypora, whose detailed recipes are given in book III of his treatise, i.e. the concoction based on quinces and the one produced from dates - AETIUs of AmidA, Iatricorum libri, III, 91, $1-92,20$.

${ }^{64}$ Cf. also a modern version of oxyporum developed for culinary use as a dressing for salad - M. GRant, Roman cookery. Ancient recipes for modern kitchens, London 1999, p. 134-135. The author terms the sauce a digestive dressing.

65 A. Dalby, Food..., p. 116-117.

${ }^{66}$ M. Кокоszко, Sosy w kuchni greckiej. Garum (garos) i pochodne, VP 26, 2006, p. 295. As such it belonged to a wide category of additives, including sauces, called hypotrimma, to which (by virtue of the inclusion) should also be attributed certain therapeutic properties. On applications of hypotrimmata in culinary art cf. IDEM, Ryby..., passim. A recipe for a certain hypotrimma is included in De re coquinaria (Apicjusz, I, 33; Apicius, I, 33). On hypotrimma and its place in dietetics cf. M. Кокоszко, K. Gibel-Buszewska, Focjusz a kuchnia grecka czyli kilka słów o abyrtake (abyrtakē), VP 28.1, 2008, p. 495-504, esp. 496-497; EIDEM, Photius and Eustathius of Thessalonica on Greek cuisine intricacies, or a few words on abyrtake (abyrtakē), Bsl 69.1, 2011, p. 114-123, esp. 115-116.

${ }^{67}$ Such were termed katachysma ( $\left.\kappa \alpha \tau \dot{\alpha} \chi v \sigma \mu \alpha\right)$. Cf. Suidae Lexicon, K, 876, 1, rec. A. AdLER, vol. I-IV, Lipsiae 1928-1935 (s.v. $\kappa \alpha \tau \dot{\alpha} \chi v \sigma \mu \alpha$, cetera: Suda). This was a generic term, referring to a variety of additives - Athenaeus of Naucratis, Deipnosophistae, IX, 399 e-f (61, 9-11, Kaibel). They were served with different dishes, for instance vegetables (edible tubers [cf. hereunder]), or meats (such as hare) - Athenaeus of Naucratis, Deipnosophistae, I, 5b (8, 23-24, Kaibel).

68 Such were termed embamma ( $" \mu \beta \alpha \mu \mu \alpha)$._The noun embamma referred to a food additive in which food was dipped. Cf. Athenaeus of Naucratis, Deipnosophistae, IX, 368a (5, 18-21, KaIBeL); Hesychii Alexandrini lexicon, Th, 119, 1-2, post I. Albertum rec. M. Sснмidt, vol. I-V, Ienae 1859-1868

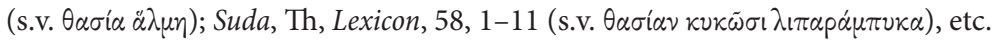


of pepper, three scripuli of seseli ${ }^{69}$, six scripuli of cardamom (and the same quantity of cumin and dried mint, as well as one scripulus of leaves $(\text { folium })^{70}$, in a mortar. Once sifted, the ingredients should be mixed with honey, and, finally, garum and vinegar ought to be added. The second recipe ${ }^{71}$ required a smaller number of ingredients: an ounce of pepper, parsley, cumin and lovage. Next, the ingredients were mixed with honey, liquamen and vinegar.

Attributing medicinal properties to various types of mixtures, of which fish sauce and vinegar were the primary ingredients, is not the exclusive feature of $D e$ re coquinaria. Medical sources offer us a number of recipes for oxygarum. As an example, we may use the surviving fragments of the deliberations of Oribasius ${ }^{72}$ and Aetius of $\mathrm{Amida}^{73}$. Their recipes are similar, although not identical, while the therapeutic action of the specifics has been stressed in the very titles of these surviving works. Both were named purifying oxygarum, i.e. oxygaron katharktikon. In both cases fish sauce and wine vinegar were mixed in equal proportions, with the remaining ingredients being added to the mix. The first recipe, namely that presented by Oribasius, includes scammony ${ }^{74}$, pepper, ginger, mint, celery seeds, vinegar, garum and honey. Aetius of Amida, in turn, cited the following important ingredients: celery seeds, pepper, ordinary caraway, asafoetida juice, scammony and equal parts of garum and vinegar. The recipe implies that saffron or common polypody could be used instead of scammony.

Medical sources indicate that the above-mentioned variants of oxygarum were served with meat and fish dishes. Galen, for example, wrote about flavouring rock fish, petraioi ichthyes ${ }^{75}$, with vinegar and garum, and about sprinkling them with pep$\mathrm{per}^{76}$. It may be that he had in mind using a certain (uncomplicated) form of oxygarum. In any case, there is hardly any doubt that the latter could have functioned as a substitute for the seasoning mentioned by the famous physician. Galen also stated that oxygarum was added when preparing leguminous plants ${ }^{77}$. These were first soaked in water, subsequently boiled until soft, and then seasoned with garum, oxygarum, or just salt.

\footnotetext{
69 Seseli tortuosum?

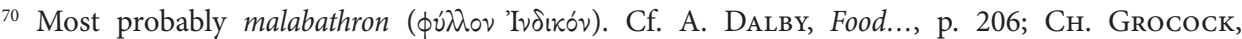
S. Grainger, Appendix I. Glossary, [in:] Apicius, p. 346-347, 350-351. Grocock and Grainger notice that in some recipes (Apicius, I, 29, 1; I, 30, 2; IX, 1, 3) their authors recommend the use of both folium and malabathrum. Authors of the Polish translation consistently interpret the term as referring to bay leaves. Cf. Apicjusz, I, 29, 1; 30, 2; IX, 1, 3.

${ }^{71}$ Apicjusz, I, 34, 2; Apicius, I, 34 (aliter).

72 Oribasius, Eclogae medicamentorum, LXXIX, 12, 1-13, 1.

73 Aetius of Amida, Iatricorum libri, III, 87, 1-5.

${ }^{74}$ Convolvulus scammonia. A description of its medicinal features cf. Aetius of Amida, Iatricorum libri, III, 25, 1-14.

75 The term rock fish referred to small, usually colorful varieties of fish living in the water close to rocky shores. They belong to the genus Labridae. Cf. M. Koкоszкo, Ryby..., p. 253-254.

${ }^{76}$ Galen, De alimentorum facultatibus, 725, 15-17.

77 GaLen, De alimentorum facultatibus, 534, 14 - 535, 2.
} 
At this point we should add that the oxygarum prepared in accordance with medical recipes was endowed with certain specific therapeutic properties, which were carefully enumerated in the analysed recipes of the aforementioned physicians. By its very nature, oxygarum was supposed to facilitate maintaining the balance of the humours. The Iatricorum libri point out that the purifying oxygarum that included scammony was supposed to remove bile. If scammony was replaced with saffron, the resulting sauce would help expel phlegm from the organism. Finally, if oxygarum was prepared with the addition of fern, the sauce stimulated the process of expelling black bile from the body.

It is worth noting here that medicine has always attributed certain medicinal properties to pure garum. These have been described in detail in treatises authored by outstanding figures of ancient and Byzantine medicine, such as Pedanius Dioscorides, Galen, Aetius of Amida and Paul of Aegina. These physicians laid emphasis on the fact that the sauce facilitated digestion ${ }^{78}$, and this property was no doubt of great importance for the author of the analysed De re coquinaria recipes. It is interesting to observe that the abovementioned medical works contain a nearly identically worded chapter devoted to the properties of garum. The sauce was described therein as a substance with strong warming and drying properties. For this reason it was used (externally) to treat festering wounds that failed to heal over an extended period of time, as well as to treat dysentery (internally) and sciatic pain $(\text { externally })^{79}$.

The De re coquinaria contains one more recipe that was connected with the usage of garum. This concerns the oenagarum in tubera (i.e. oenogarum used for truffles). Essential ingredients included pepper, lovage, coriander, rue, garum, honey, wine and a small amount of oil. As the title indicates, the mixture was used as a truffle sauce. In medical sources, however, similar recipes are relatively common, while oenogarum was thought to have specific therapeutic properties. For example, Aetius of Amida ${ }^{80}$ mentions a specific mixture that was made using two parts of fish sauce per one part of wine. In all probability, the type of wine was not important, for Aetius fails to provide a description thereof. Honey was added in order to give the mixture some sweetness. The oenogarum version known from Iatricorum libri contains a number of additional ingredients. The context implies that these were added in order for the sauce to gain the desired therapeutic - i.e. purifying - properties. For this reason Aetius' specific is known as the purifying oenogarum, i.e. oinogaron katharktikon.

\footnotetext{
${ }_{78}$ On the feature of garum cf. GALEN, De alimentorum facultatibus, 725, 6- 726, 4.

79 The most informative characteristics cf. Pedanii Dioscuridis Anazarbei liber, II, 32, 1, 1-4, [in:] Pedanii Dioscuridis Anazarbei de materia medica libri quinque, ed. M. Wellmann, vol. I-III, Berolini 1906-1914 (cetera: Dioscurides, De material medica); Galeni de simplicium medicamentorum temperamentis et facultatibus libri, 377, 6-9, [in:] Claudii Galeni opera omnia, ed. D.C.G. KüHN, vol. XI-XII, Lipsiae 1826-1827; Aetius of Amida, Iatricorum libri, II, 150, 1-3; Paul of Aegina, Epitome, VII, 3 , $3,21-23$.

80 Aetius of Amida, Iatricorum libri, II, 86, 1-5.
} 
The recipe would seem to imply that it was standard practice to enrich the oenogarum proper with pepper and lovage, and optionally with scammony (in order to remove bile from the organism), saffron (to expel phlegm) or common polypody (if the objective of serving the oenogarum was to expel black bile).

Sales conditi are yet another example of a food additive to which medicinal properties were ascribed. The therapeutic application of the next recipe contained in the De re coquinaria is clearly visible in the introduction to the analysed recipe. According to its author, herbal salts facilitated digestion, counteracted indigestion, and had a purgative effect. They were also supposed to prevent numerous illnesses (omnes morbos), epidemic diseases ${ }^{81}$ and fevers. The necessary ingredients included one libra ${ }^{82}$ of fine salt, two librae of ammonium salt, three ounces of white pepper, two ounces of ginger, one and a half ounce of ajowan $(\mathrm{ammi})^{83}$, the same quantities of thyme, celery seeds, or three ounces of parsley, three ounces of oregano, one and a half ounce of rocket seeds, three ounces of black pepper, one ounce of saffron, two ounces of Cretan hyssop, two ounces of leaves (folium), and the same quantities of parsley and garden dill.

We are of the opinion that the mixture thus prepared was used to season heavy dishes. Thus, the salts would not only improve their taste, but also facilitate the digestive process and the purging of the organism of harmful products of metabolism. Similar spice mixes may be found in the works of Aetius of Amida, who left us three recipes for salt with vegetable additives, which he called 'purifying', hales katharktikoi, as a whole ${ }^{84}$.

Now let us move on to the beverages. Conditum ${ }^{85}$ was a type of spiced wine. We learn from De re coquinaria that its ingredients, if added in the appropriate proportions, prevented the rapid deterioration of the alcoholic beverage, and therefore it could be taken by travellers embarking on long voyages ${ }^{86}$. The preparation of this wine was rather time-consuming, for a number of stages were required. First, two sextarii of wine and fifteen pounds of honey were poured into a copper vessel. This mixture was then heated over a slow fire made from dry wood and mixed with a wooden spatula in order to prevent burning the ingredients. Next, the vessel was taken off of the fire and set aside to cool. The boiling and cooling sequence was repeated three times. Only then was the honey skimmed ${ }^{87}$, and successive ingredi-

\footnotetext{
${ }^{81}$ The English translators understand pestilentiam as plague.

${ }^{82}$ Libra $=327.4$ grams.

83 Trachyspermum ammi. Cf. A. Dalby, Food..., p. 109.

${ }^{84}$ Aetius of Amida, Iatricorum libri, III, 110, 1-9.

${ }^{85}$ We mean both the wines specified in De re coquinaria, i.e. conditum papardoxum as well as conditum melizomum viatorum.

${ }^{86}$ This suggestion is included in the title of the other of the two above-mentioned recipes. Cf. A. DALBY, Food..., p. 95

${ }^{87}$ Grocock and Grainger (Apicius, III, 1, 1, p. 133) translate the phrase - and it is skimmed the day after. Although the Latin text is far from clear, we would like to suggest that the author of the recipe
} 
ents added: a portion of the same wine that was previously mixed and boiled with the honey, four ounces of ground pepper, three scripuli of mastic, one drachm ${ }^{88}$ of saffron and one of folium, five roasted date seeds, and five dates soaked in wine. Finally, eighteen sextarii of weak wine were added. In order to remove the smoky aftertaste, glowing charcoal could be put into the vessel.

The second recipe is concerned with conditum melizomum viatorum, that is, a wine with honey that was intended for travellers. Its preparation was not difficult. Once the honey was skimmed (and maybe after it had been boiled three times), one should add ground pepper and then the quantity of honey mixed with wine that would be required by the traveller. This alcoholic beverage must have been rather thick, for the author of the recipe emphasises that if necessary it should be diluted with wine. Without a doubt, the pepper and honey served to preserve the wine.

In this instance, too, we find analogous recipes in medical writings. In his works, Oribasius included a recipe for a simple base conditum, which - as we should suppose - had a general action ${ }^{89}$, and three recipes for condita helping cure the urinary system (two recipes for condita alleviating ailments of the urinary system in his Eclogae alimentorum ${ }^{90}$, and one for an alcoholic beverage facilitating the dissolution of calculus in the urinary bladder inserted in Collectiones medi$\left.c a e^{91}\right)$. As a matter of fact, a recipe analogous to the latter group of prescriptions has also survived in Epitome authored by Paul of Aegina ${ }^{92}$. Finally, we should add that Aetius of Amida has provided us with three recipes for condita that were supposed to provide relief in ailments connected, as we may surmise, with specific temperaments, i.e. with excess bile ${ }^{93}$, black bile ${ }^{94}$ and phlegm ${ }^{95}$. They altogether constitute unequivocal proof of the (unspecified in De re coquinaria, however, very likely) medical applications of conditum that we know from De re coquinaria.

Melizomum, in turn, is with all certainty analogous to oinomeli, which in Latin was usually called mulsum ${ }^{96}$. This was a wine sweetened with honey, usually

might have meant that the mixture of honey and wine (in which honey was the dominant ingredient) should have been skimmed three times (possibly the following day after each of the triple boiling), since careful boiling and subsequent removal of foam from the surface of honey was a normal procedure recommended to get rid of its ability to irritate the bowels - GALEN, De alimentorum facultatibus, $740,13-741,3$. Moreover, skimmed honey is expressis verbis mentioned (cum melle despumato) in the recipe for conditum melizomum viatorum.

${ }_{88}$ Drachm $=4.3$ grams.

${ }^{89}$ Oribasius, Collectiones medicae, V, 33, 9, 1-3.

90 Oribasius, Eclogae medicamentorum, 62, 8, 1 - 9, 3.

91 Oribasius, Collectiones medicae, V, 33, 8, 1-6.

92 Paul of Aegina, Epitome, VII, 11, 49, 1-4.

93 Aetius of Amida, Iatricorum libri, III, 66, 1-4.

94 Aetius of Amida, Iatricorum libri, III, 68, 1-3.

95 Aetius of Amida, Iatricorum libri, III, 67, 1-3.

${ }^{96}$ Cf. identification proposed in Ch. Grocock, S. Grainger, Appendix I. Glossary..., p. 351. 
prepared immediately before a meal. The recipe for this alcoholic beverage has survived to our times among others in the writings of Oribasius ${ }^{97}$ and in the Geoponica $^{98}$.We learn, for instance from Aetius of Amida, that, depending on tastes and requirements, it could be enriched with herbs and spices, thereby acquiring therapeutic properties, for example regulating defecation ${ }^{99}$, and the generation of phlegm ${ }^{100}$, bile ${ }^{101}$ and black bile ${ }^{102}$.

According to the recipe from De re coquinaria, Roman absinthe was prepared using instructions provided for Camerinian wine. Next, one should add one ounce of ground and purified Pontic wormwood, one Theban date, mastic and three scripuli of folium, six scripuli of a plant called costus ${ }^{103}$, the same quantity of saffron and eighteen sextarii of wine. If the wine turned out to be too bitter, one could improve its taste using charcoal, which decreased the presence of bitterness in the alcoholic beverage. The piece of advice how to prepare the beverage contained in De recoquinaria is a variant of a recipe that had been popular in the Mediterranean Basin for a long time. The addition of wormwood resulted in a wine that Dioscorides ${ }^{104}$ and Oribasius ${ }^{105}$ termed oinos absinthites. According to the information included by Anthimus in De observatione ciborum, it is called aloximum ${ }^{106}$. The recipe for its preparation may be found, among others, in Geoponica ${ }^{107}$. The tradition associated with its production was uninterrupted, most probably due to its therapeutic properties. It was considered that the wine positively impacted the functioning of the stomach, facilitated the generation of urine and regulated the functioning of the liver ${ }^{108}$.

In turn, the rose wine (rosatum) mentioned in the De re coquinaria, or more appropriately an alcoholic beverage with the addition of roses or violets, was prepared in the following manner. Once the white parts were removed from rose petals, they were placed on a piece of flax linen, which was then made into a bundle.

97 Oribasius, Collectiones medicae, V, 25, 10, 1 - 14, 1 .

98 Geoponica, VIII, 25-26.

99 Aetius of Amida, Iatricorum libri, III, 62, 1-5.

${ }^{100}$ Aetius of Amida, Iatricorum libri, III, 64, 1-3.

${ }^{101}$ Aetius of Amida, Iatricorum libri, III, 63, 1-3.

102 Aetius of Amida, Iatricorum libri, III, 65, 1-2.

${ }^{103}$ Saussurea lappa. A typical Byzantine description - Aetius of Amida, Iatricorum libri, I, 219, 1-12. See also: A. DALby, Dangerous tastes..., p. 85-86; IDEM, Empire..., p. 197; IDEM, Food..., p. 105; IDEM, Flavours..., p. 206; М. Kокоszко, Krótki komentarz do kilku terminów urobionych od rzeczownika „karyke” (karykē), PNH 7.1, 2008, p. 6-7; IDEM, Some technical terms from Greek cuisine in classical and Byzantine literature, E 95, 2009, p. 270.

${ }^{104}$ Dioscurides, De materia medica, V, 39, 1,1 .

${ }^{105}$ Oribasius, Collectiones medicae, V, 25, 39, 2. Cf. A. Dalby, Flavours..., p. 182.

${ }^{106}$ Anthimus, De observatione ciborum, XV. Cf. M. Grant, Commentary on the text, [in:] Anthimus, De observatione ciborum, p. 92.

${ }^{107}$ Geoponica, VIII, 21.

${ }^{108}$ Dioscurides, De materia medica, V, 39, 3, 4-8; Oribasius, Collectiones medicae, V, 25, 40, 1-4. 
This was placed in wine and left to soak for seven days. When the first portion was removed, the next was subjected to the same treatment, being left in the beverage for an identical period. This activity was repeated a third time, after which the bundle was removed and the wine strained; finally, before drinking, honey was added. The author notes that violet wine, namely violacium could be prepared in an identical manner.

Wines of this type are frequently mentioned in medical treatises. These recipes show that just as De coquinaria alcoholic beverage, they were made using rose petals ${ }^{109}$. The medicinal wines of this type were known as oinos rodites ${ }^{110}$ or, simply, as rosaton ${ }^{111}$. Its popularity remained undiminished over time ${ }^{112}$, since in the $10^{\text {th }}$ cent. a recipe for rosatum became part of the eighth book of Geoponica ${ }^{113}$. Physicians wrote that it was useful for treating dysenter $y^{114}$, and also, as Aetius of Amida confirms, for expelling bile ${ }^{115}$.

Coming back to foods, we should also mention that the authors of De re coquinaria introduced yet another dish which was eaten for the sake of preserving health, i.e. pulmentarium. Grocock and Grainger maintain that the term pulmentarium means any food eaten with bread, a relish to accompany bread as the main part of the meal ${ }^{116}$. Since in De re coquinaria we can find as many as five recipes for the delicacy, we may surmise that it was quite popular. Neither did it require costly ingredients, because it was based on easily available vegetables. As for its physical characteristic, we may assume that the author of the recipe was probably referring to a thick, albeit liquid additive used to moisten bread or to be placed on (or maybe scooped with) bits of bread.

The therapeutic action of the dish is clearly stated in the titles of the group of recipes ${ }^{117}$. The Polish translation of the subtitle of the group of recipes indicates that pulmentarium ad ventrem is a zupa na żoładek ('soup for the stomach'). Additionally, the translators, namely Professors Ireneusz Mikołajczyk

\footnotetext{
${ }^{109}$ W.I. CARTER, Roses in antiquity, An 14, 1940, p. 250-256. One should also remember of another recipe from De re coquinaria (Apicjusz, I, 4, 2; Apicius, I, 4, 2), which recommends preparing another rosatum, this time without roses (sine rosa). Instead of the rose petals citron (Citrus medica) leaves were made use of.

${ }^{110}$ Dioscurides, De materia medica, V, 27, 1, 1; Oribasius, Collectiones medicae, V, 25, 25, 2.

${ }^{111}$ Oribasius, Collectiones medicae, V, 33, 1, 1 - 5, 4; Aetius of Amida, Iatricorum libri, III, 73, 1.

${ }^{112}$ A. DALby, Food..., p. 284. An analysis of data taken from the treatises authored by Herophilus and Oribasius - IDEM, Flavours..., p. 180-181.

${ }^{113}$ Geoponica, VIII, 2.

${ }^{114}$ Dioscurides, De materia medica, V, 27, 2, 1-2; Oribasius, Collectiones medicae, V, 25, 26, 1-2.

${ }^{115}$ Aetius of Amida, Iatricorum libri, III, 73, 1-8.

${ }^{116}$ Apicius, p. 159, an. 2.

${ }^{117}$ Pulmentarium ad ventrem - Apicjusz, III, 2 (the Polish translators treat the expression as the title of the whole subchapter); Apicius, III, 2, 1 (the English translators include the expression in the title of the first recipe); aliter ad ventrem - Apicjusz, III, 2, 3; Apicius, III, 2, 2; aliter ad ventrem - Apicjusz, III, 2, 5; Apicius, III, 2, 4.
} 
and Sławomir Wyszomirski, are of the opinion that these recipes are in actual fact recommendations taken from unknown medical treatises ${ }^{118}$. In their English translation in turn, Christopher Grocock and Sally Grainger do not mention such a possibility. Moreover, they translate the term in question as easily digested relish, which seems to us a little awkward since imprecise. However, their rendering of the subtitle aliter ad ventrem as alternatively for digestion, dispels the doubt and clearly proves that they also accept the meaning of the title suggesting a dish or a complex food additive thought to have a beneficial effect on the process of digestion. Consequently, we may opine that the pulmentarium in question was a kind of food to be administered in the event of stomach ailments, although of course its consumption did not have to be conditioned solely by a poor state of health.

In accordance with the recipes included in the work, pulmentarium was made from beets ${ }^{119}$, celery and leeks ${ }^{120}$, from beetroot and leeks ${ }^{121}$ or from common polypody ${ }^{122}$. Only one of the recipes clearly mentions that the vegetable should be cut up ${ }^{123}$. There is also one reference to the fact that beets were prepared in bundles ${ }^{124}$, in water and with the addition of soda in order to let them preserve their freshly green colour ${ }^{125}$. They, however, were also cooked in wine sweetened with honey, salted with a pinch of salt and finished by adding olive oil ${ }^{126}$. Before serving, the vegetables were sometimes boiled in a sauce made from pepper, cumin, fish sauce and raisin wine (Latin passum - this beverage added sweetness) ${ }^{127}$. According to another recipe, the sauce included boiled must or raisin wine, a small quantity of olive oil, cumin and pepper. Once the mixture had boiled,

\footnotetext{
${ }^{118}$ S. Wyszomirski, I. MiкоŁajczyк, Przypisy do ksiegi III, [in:] Apicjusz, p. 268, an. 2.

${ }^{119}$ Apicjusz, III, 2, 3-4; Apicius, III, 2, 2-3. The other recipe calls for beta nigra (black beets), which is a variety of Beta vulgaris. Cf. J. ANDrÉ, L'alimentation et la cuisine a Rome, Paris 1961, p. 18; A. DALBY, Food..., p. 51; M. Koкоszко, Smaki Konstantynopola..., p. 525-525; M. Koкоszко, K. JaGusiak, Warzywa..., p. 44-45.

${ }^{120}$ Apicjusz, III, 2, 5; Apicius, III, $2,4$.

${ }^{121}$ Apicjusz, III, 2, 1; Apicius, III, 2, 1.

${ }_{122}$ Apicjusz, III, 2, 1; Apicius, III, 2, 1.

${ }^{123}$ We mean the recipe for preparing polypody - Apicjusz, III, 2, 2; Apicius, III, 2, 1. As for beets there is a difference in the translations. Notably, the words betas minutas et porros (...) are translated by Mikołajczyk and Wyszomirski as małe buraczki i (...) pory ('small beets and ... leeks'). Grocock and Grainger render minutas as a participium perfecti passivi from the verb minuo; ere. Accordingly, they translate minutas as 'chopped. Cf. Apicius, III, 2, 1.

${ }^{124}$ Apicjusz, III, 2, 3; Apicius, III, 2, 2.

${ }_{125}$ Apicjusz, III, 1; Apicius, III, 1.

${ }^{126}$ Apicjusz, III, 2, 4; Apicius, III, 2, 3. From the recipe we can learn that the dish could be also prepared with the addition of chicken. Chicken meat was very popular and generally appreciated. Cf. M. Кокоszко, Smaki Konstantynopola..., p. 495-496; M. Кокоszко, Ł. ErLICH, Rola mięsa w diecie późnego antyku i wczesnego Bizancjum na podstawie wybranych źródeł literackich, Część I, Zwierzęta hodowlane w sztuce kulinarnej oraz teorii dietetycznej, PZH 12.1, 2011, p. 23-25.

${ }^{127}$ Apicjusz, III, 2, 1; Apicius, III, 2, 1.
} 
it was enriched with common polypody ground in a mortar, pieces of nuts and garum $^{128}$. Another though analogous method of preparing the dish consisted in stewing the white parts of leeks, previously boiled in water, in a marinade made up of ground pepper, fermented fish sauce and liquid honey. The final ingredient to be added to the dish was celery stock (and celeries themselves provided one liked the ingredient) ${ }^{129}$.

The next dish, namely tisana, or - in Greek - ptisane, was very famous. It is the subject of two recipes in the De re coquinaria. The first, i.e. tisana vel sucus, was prepared in the following manner. One day before boiling, the cook would soak pearl barley in water, which was then washed and ground, and placed over a strong fire in a pot. When it was soft, the cook added olive oil, a bunch of dill, dried onions, summer savory and a knuckle ham bone. Next, the mixture was boiled until the meat became soft, and coriander ground with salt was added. The dish was boiled yet again, and the dill and pearl barley - insofar as possible - removed. The barley was then placed in another pot and reground while keeping the vessel over a fire and making sure not to burn the pearl barley. The pulp was then transferred to the pot containing the pork and broth, and the cook would add ground lovage, dried field mint, Roman caraway, asafoetida $a^{130}$, a small quantity of wine vinegar, boiled must and garum. Finally, the mixture was boiled yet again and served.

The second variant, namely the recipe for tisana barrica, recommended the following ingredients. Soaked chick peas, lentils and peas. Pearl barley was washed, added to the above ingredients and boiled in good quality potable water. When the constituents were soft, the cook would add olive oil and finely chopped leeks, cut up coriander, dill, fennel, beetroot, mallow and young cabbage stalks. Additional cabbage stalks were boiled separately, ground into a pulp and mixed with fennel seeds, oregano, asafoetida, lovage and fish sauce. Everything was put into one pot with the boiled cicer, lentils and peas. In the end, finely chopped cabbage stalks were added and the dish was served.

The dish that the author of the recipe calls tisane is well known to us as the Greek ptisane. This is the name that was given to it in medical sources as early as in Corpus Hippocraticum, where the term appears a high number of time, for instance,

\footnotetext{
${ }^{128}$ Apicjusz, III, 2, 3; Apicius, III, 2, 2.

${ }^{129}$ Apicjusz, III, 2, 5; Apicius, III, 2, 4.

${ }^{130}$ Ferula asafoetida. In Greek it was usually called silphion. On the spice cf. A.C. Andrews, The silphium of the ancients. A lesson in crop control, Is 33, 1941, p. 232-236; A. ArndT, Silphium, [in:] Spicing up the palate. Proceedings of the Oxford symposium on food and cookery (1992), Blackawton-Totnes 1993, p. 28-35; A. Dalby, Silphium and asafoetida. Evidence from Greek and Roman writers, [in:] Spicing..., p. 62-72; IDEM, Food..., p. 29, 42, 303-304; M. Koкoszko, Smaki Konstantynopola..., p. 555-556; IDEM, Aromaty..., p. 562-563; D. Roques, Médecine et botanique. Le silphion dans l'œuvre d'Oribase, REG 106, 1993, p. 380-399.
} 
in the treatise De diaeta in morbis acutis ${ }^{131}$. We are also informed that it was discussed by at least two representatives of the Alexandrian school, namely Diocles and Phiotimus ${ }^{132}$.

What then was the ptisane? Available information indicates that it was a dish with a therapeutic action, with the consistency of a beverage (and in that case usually termed chylos ptisanes ${ }^{133}$ ) or gruel, and made from pearl barley. Galen's writings $^{134}$ (as well as those of Oribasius ${ }^{135}$ quoting doctrines of his master) inform us that it was prepared from soaked, ground barley seeds, which were boiled in water over a slow fire until they swelled, with the addition of wine vinegar and olive oil. When the grain became soft, it was seasoned with fine salt, and sometimes with leeks and fennel. The dish thus prepared was supposed to purify ${ }^{136}$ and moisten the body ${ }^{137}$. The physician Anthimus, who lived in the $6^{\text {th }}$ cent. and composed the treatise entitled De observatione ciborum, also wrote about its favourable impact on both healthy persons and those suffering from fever, while the information which he provides clearly indicates that the dish was prepared not only as a medicine, but could also constitute a nutritious daily meal ${ }^{138}$. An interesting recipe that supplements the above data may be found in the Epitome of Paul of Aegina. Paul of Aegina maintained that a sui generis soup may be prepared for medicinal purposes, which was made from one part of barley per fifteen parts of water and olive oil, with vinegar being added once the barley swells. After boiling, a small amount of leeks or dill would be added. The learned physician also added that a similar ptisane was usually cooked from oats and chondros (emmer groats). The resulting soup moistened and purified the body ${ }^{139}$.

Finally, we should touch upon the issue of nettles. The author of De re coquinaria recommended to harvest nettles when the Sun is in Aries ${ }^{140}$ and consume them in order to prevent illness. However, he provided no further information concerning the latter. A similar comment was included by Pliny the Elder in his Historia naturalis ${ }^{141}$, where he states that the plant is a prophylactic agent that helps prevent ailments brought about by successive seasons of the year.

\footnotetext{
${ }^{131}$ For example - Hippocrate, De diaeta in morbis acutis, IV, 1 - VI, 27, [in:] Oeuvres completes d'Hippocrate, vol. II, ed. E. LitTre, Amsterdam 1961.

${ }^{132}$ GALEN, De alimentorum facultatibus libri, 496, 10-13.

${ }^{133}$ For example - Oribasius, Collectiones medicae, IV, 11, 1, 1-14, 4 .

${ }^{134}$ For example - Galen, De alimentorum facultatibus, 502, 7 - 504, 4. Cf. E. Darmstaedter, Ptisana: ein beitrag zur Kenntnis der antiken Diaetetik, Ar.ASS 15, 1933, p. 181-201.

${ }^{135}$ Oribasius, Collectiones medicae, IV, 1, 15, $1-22,1$.

${ }^{136}$ Aetius of Amida, Iatricorum libri, II, 260, 1.

${ }^{137}$ Aetius of Amida, Iatricorum libri, I, 225, 11-12.

${ }_{138}$ Anthimus, De observatione ciborum, 64.

139 Paul of Egina, Epitome, I, 78, 1, 21-25.

${ }^{140}$ Between the $21^{\text {st }}$ March and the $29^{\text {th }}$ April.

${ }^{141}$ Pliny, Natural History, XXI, 93 trans. H. Rackham, London-Cambridge Mass., 1938-1963.
} 
We present the opinion that in this case, too, the teachings contained in the analysed cookery book were a result of simplifying medical theories and employing them for the sake of healthy cuisine. The conclusion is based on numerous references to nettles in medical writings. Galen ${ }^{142}$, Oribasius ${ }^{143}$ and Aetius of Amida $^{144}$ discussed them in detail. Galen, for instance, classified them as mainly wild-growing plants. He, however, also stated that they were usually overlooked in the daily diet, and consumed solely in periods of famine $e^{145}$. One may therefore surmise that the poorer classes also used nettles in various other circumstances to supplement their poor daily diet. The conclusion can be formed on the basis of the same passage from the medic's De alimentorum facultatibus since nettles were highly recommended by Galen as an additive to bread, i.e. opson. Ultimately, from Galen's text we also learn that the plants, when used as a medicine, since they facilitated purgation.

To sum up our deliberations, we should state that the analysis set forward hereabove indicates that the authors of De re coquinaria, even if they were not medical experts, remained under a considerable influence of Hippocratic and Galenic doctrines. For this reason, they took them into consideration (intentionally or not, however, the first option seems more likely in the light of the spread of Hippocratic and Galenic teachings) in their culinary practice and writings. Thus, De re coquinaria is yet another work of antiquity that attests to close connections existing between medical doctrines and culinary practice of the times.

\begin{abstract}
The article is aimed at indicating and analyzing connections existing between De re coquinaria and medicine. It is mostly based on the resources of extant Greek medical treatises written up to the $7^{\text {th }}$ century A.D. As such it refers to the heritage of the Corpus Hippocraticum, Dioscurides, Galen, Oribasius, Anthimus, Aetius of Amida, Paul of Aegina, to name but the most important.

The authors of the study have tried to single out from De re coquinaria those recipes which have the tightest connections with medicine. They are: a digestive called oxyporum, two varieties of dressings based on fish sauce, i.e. oxygarum digestibile and oenogarum, herbal salts (sales conditi), spiced wine (conditum paradoxum), honeyed wine (conditum melizomum viatorum), absinthe (absintium Romanum), rosehip wine (rosatum), a soup (or relish) pulmentarium, a pearl barley-based soup termed tisana vel sucus or tisana barrica, an finally nettles. In order to draw their conclusions, the authors of the article projected the data from De re coquinaria upon a wide background of extant information retrieved from medical writings.
\end{abstract}

\footnotetext{
${ }^{142}$ For instance - GALEN, De alimentorum facultatibus, 639, 13-17.

${ }^{143}$ For instance - Oribasius, Collectiones medicae, III, 14, 1, 1-2.

${ }^{144}$ Aetius of Amida, Iatricorum libri, I, 13, 1-9.

${ }^{145}$ On emergency foods in medical writings cf. M. Кокоszко, K. Gibel, Dieta mnichów syryjskich. Komentarz do terminu autofya lachana w Historia religiosa Teodoreta z Cyru, [in:] Omnia tempus habent. Miscellanea theologica Vincentio Myszor quadragesimum annum laboris celebranti ab amicis, sodalibus, discipulisque oblata, ed. A. RegineK, G. StrzelczyK, A. ŻąDŁo, Katowice 2009, p. 145-156.
} 
The conclusions demonstrate that those who contributed to the present form of De re coquinar$i a$, even if they did not possess strictly medical expertise, remained under a heavy influence of Hippocratic and Galenic teachings. As a result, De re coquinaria should be seen as yet another work of antiquity that supports the existence of an indissoluble bond between medical doctrines and culinary practice of the times.

Maciej Kokoszko

Katedra Historii Bizancjum

Wydział Filozoficzno-Historyczny

Uniwersytet Łódzki

ul. A. Kamińskiego 27a

90-219 Łódź, Polska

mkokoszko@komandor.pl

Zofia Rzeźnicka

Katedra Historii Bizancjum

Wydział Filozoficzno-Historyczny

Uniwersytet Łódzki

ul. A. Kamińskiego 27a

90-219 Łódź, Polska

zofia_pwp.historyk@wp.pl

Krzysztof Jagusiak

Katedra Historii Bizancjum

Wydział Filozoficzno-Historyczny

Uniwersytet Łódzki

ul. A. Kamińskiego 27a

90-219 Łódź, Polska

krzysztof_jagusiak@o2.pl 